\section{Increased Survival of Penaeus monodon Larvae Treated with Vibrio harveyi Bacterin}

\author{
Zafran $^{1}$, Fris Johnny ${ }^{1}$, Des Roza ${ }^{1}$, Isti Koesharyani ${ }^{1}$ \\ and Kishio Hatai ${ }^{2}$ \\ ${ }^{1}$ Gondol Research Station for Coastal Fisheries, $P O$ \\ Box 140, Singaraja (81101) Bali, Indonesia \\ ${ }^{2}$ Division of Fish Diseases, Nippon Veterinary and Animal \\ Science University, 1-7-1 Kyonan-cho, Musashino, \\ Tokyo 180-8602, Japan
}

(Received February 27, 1998)

Key words: bacterin, Penaeus monodon, protection, Vibrio harveyi

Indonesian reports of luminescent vibriosis outbreaks in larval black tiger shrimp Penaeus monodon in hatcheries result in serious damage to the seed production. Causative agent of infection was identified as Vibrio harveyi ${ }^{1-3)}$. This bacterium may infect not only zoeal larvae, but also mysis and postlarvae.

Control of the luminiscent of $V$. harveyi infection has been attempted by using some chemicals and antibiotics, but the disease has not been controlled. Toxicity of chemicals to the larvae and drug resistance acquired by the pathogen have been considered as negative impact of the chemotherapy.

Some works have been done on the resistance to bacterial disease and defense mechanisms of crustaceans ${ }^{4-9}$. Therefore, we attempted to develop a treatment with bacterin for prevention of luminescent vibriosis in P. monodon at hatchery.

A bacterin was prepared as follows: $V$. harveyi GSB-9103, which was isolated from diseased postlarvae in 1991, was inoculated on tryptic soya agar and incubated at $27^{\circ} \mathrm{C}$ for $48 \mathrm{~h}$. The bacteria were then collected and killed with $0.5 \%$ formalin. After the suspension was washed three times by centrifugation at $1000 \times \mathrm{g}$ for $20 \mathrm{~min}$, it was streaked onto marine agar plates and incubated overnight at $27^{\circ} \mathrm{C}$ to verify wether the bacteria were killed. The number of bacteria in the suspension was adjusted to $10^{10} \mathrm{cfu} / \mathrm{m} l$ and stored at $4^{\circ} \mathrm{C}$ until use.

Nauplii of $P$. monodon, obtained from a commercial hatchery at Situbondo, East Java in June 1996, were used for the experiment of bacterin bath. The nauplii were divided into five groups according to different bathing time, namely $2 \mathrm{~h}, 3 \mathrm{~h}$, $4 \mathrm{~h}, 5 \mathrm{~h}$, and without bacterin bath as a control. Two hundred nauplii were used for each group. The larvae then were reared in $2 l$ bottles containing sterile sea water at $30 \pm 1{ }^{\circ} \mathrm{C}$ and $32 \%$ salinity. This experiment utilized a completely randomized design with three replications. The larvae were kept under the condition for 7 days until they reached postlarvae-1, and then the postlarvae were submitted to the challenge test with $V$. harveyi GSB-9103.

The experiments were made by dipping the larvae from each group in a suspension of live $V$. harveyi GSB-9103. Survival rates of the larvae were recorded daily for five days. The num- ber of bacteria in the suspension was adjusted to $1.2 \times 10^{6} \mathrm{cfu} /$ $\mathrm{m} l$. Potency of bacterin is expressed in terms of relative percent survival (RPS) ${ }^{10)}$ as follows:

$$
\text { RPS }=\left(1-\frac{\% \text { vaccine mortality }}{\% \text { control mortality }}\right) \times 100
$$

The survival rates of bacterin bathed larvae (nauplius, zoea, and mysis) were higher than untreated animals (Table 1). The larvae bathed for $5 \mathrm{~h}$ showed higher survival rates than another groups. These data showed that bacterin bath may providing some protection against disease and has no negative effect to the larvae.

The bacterin administered by bathing enhanced the survival rates in $P$. monodon postlarvae experimentally challenged with luminescent $V$. harveyi (Table 2). In the studies on protection enhancement in some crustaceans, American lobster Homarus americanus $^{8)}$, kuruma prawn $P$. japonicus ${ }^{5), 7)}$, tiger shrimp $P$. monodon $^{4), 6), 11)}$ have succesfully been treated with bacterins. Both immersion and oral administration of $V$. vulnificus bacterin enhanched the growth rate of culture tiger shrimp ${ }^{11), 12}$. The mechanism of better growth probably comes from the disease resistance of shrimp ${ }^{9}$. From our results, it was also demonstrated that the bacterin bath in P. monodon larvae provided the protection against $V$. harveyi infection. There are not enough data in the present study to discuss the mechanism.

Table 1. Survival rates (\%) of Penaeus monodon in larval stages (nauplius, zoea and mysis) bath treated with Vibrio harveyi bacterin for different periods

\begin{tabular}{ccc}
\hline Bath treatment & $\begin{array}{c}\text { Survival rate (\%) at } \\
\text { 5days after challenge* }\end{array}$ & $\begin{array}{c}\text { RPS at 5 days } \\
\text { after challenge }\end{array}$ \\
\hline Control & 53.2 & - \\
$2 \mathrm{~h}$ & 61.5 & 17.8 \\
$3 \mathrm{~h}$ & 64.7 & 24.6 \\
$4 \mathrm{~h}$ & 66.8 & 29.2 \\
$5 \mathrm{~h}$ & 70.2 & 30.3 \\
\hline
\end{tabular}

* 600 larvae were used in each test group.

Table 2. Relative percent survival (RPS) of bath-treated Penaeus monodon postlarvae following challenge with Vibrio harveyi GSB-9103

\begin{tabular}{cccccc}
\hline \hline & \multicolumn{5}{c}{ RPS } \\
\cline { 2 - 6 } Bath treatment* $^{*}$ & $24 \mathrm{~h}$ & $48 \mathrm{~h}$ & $72 \mathrm{~h}$ & $96 \mathrm{~h}$ & $24 \mathrm{~h}$ \\
\hline 2 h & 57.1 & 29.2 & 20.0 & 25.3 & 20.3 \\
$3 \mathrm{~h}$ & 71.4 & 41.7 & 35.4 & 36.8 & 33.6 \\
$4 \mathrm{~h}$ & 71.4 & 47.9 & 47.8 & 47.4 & 43.7 \\
$5 \mathrm{~h}$ & 92.8 & 75.0 & 63.1 & 69.5 & 67.2 \\
\hline
\end{tabular}

* 300 larvae were used in each test group. 


\section{REFERENCES}

1) Lavilla-Pitogo, C. R., L. J. Albright, M. C. Paner and N. A. Sunaz (1992): Diseases in Asian aquaculture I, pp. 81-87. 2) Rukyani, A., P. Taufik and Taukhid (1992): Proceed. CRIFI, Indonesia, 24, 47-58. 3) Zafran, D. Roza Boer, K. Sugama, S. Wada and K. Hatai (1994): Proceed. Third Asian Fish. Forum, 294-297. 4) Adams, A. (1991): Fish and Shellfish Immunol., 1, 59-70. 5) Itami, T., Y. Takahashi and Y. Nakamura (1989): J. Aquat. Anim. Health, 1, 238-242. 6) Itami, T., Y. Takahashi, K. Yoneoka and Y. Yan (1991): J.
Aquat. Anim. Health, 3, 151-152. 7) Itami, T., Y. Takahashi, E. Tsuchihira, H. Igusa and M. Kondo (1994): Proceed. Third Asian Fish. Forum, 375-378. 8) Paterson, W. D. and I. R. Keith (1992): Diseases in Asian aquaculture I, pp. 294297. 9) Sung, H. H., G. H. Kou and Y. L. Song (1994): Fish Pathol., 29, 11-17. 10) Amend, D. F (1981): Develop. Biol. Standard, 49, 447-454. 11) Sung, H. H., Y. L. Song and G. H. Kou (1991): Fish Shellfish Immunol., 1, 311-312. 12) Song, Y. L. and H. H. Sung (1990): Bull. Eur. Assoc. Fish Pathol., 10, 98-99. 